\title{
The Role Vascular Endothelial Growth Factor, Control Glycemic, Lipid Profile, and Hypoxia-inducible Factor 1-Alpha at Type 2 Diabetic Patients in North Sumatera, Indonesia
}

\author{
Rusdiana Rusdiana ${ }^{1 * \mathbb{D}}$, Sry Suryani Widjaja ${ }^{1}$, Rina Amelia $^{2}$, Siti Syarifah $^{3}$, Rusmalawati Rusmalawati $^{4}$ \\ ${ }^{1}$ Departement of Biochemistry, Medical Faculty, Universitas Sumatera Utara, Medan, Indonesia; ${ }^{2}$ Department of Community \\ Medicine and Public Health, Medical Faculty, Universitas Sumatera Utara, Medan, Indonesia; ${ }^{3}$ Department of Pharmacology \\ and Therapeutic, Medical Faculty, Universitas Sumatera Utara, Medan, Indonesia; ${ }^{4}$ Department of Public Health, Universitas \\ Sumatera Utara, Medan, Indonesia
}

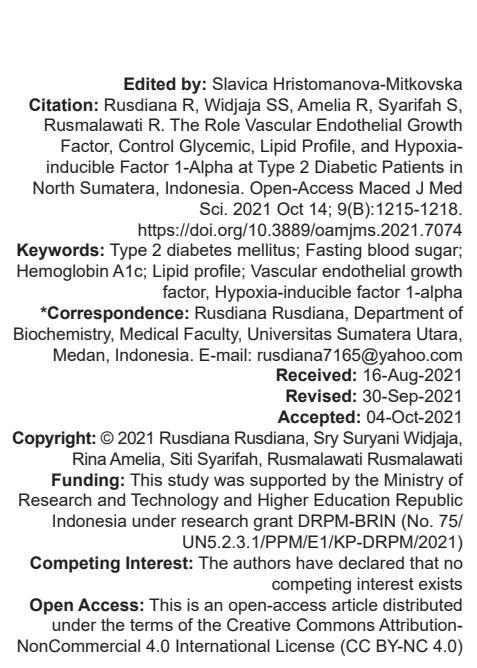

Introduction

Type 2 diabetes mellitus (T2DM) is responsible for increasing associated vascular complications, leading to considerable morbidity and mortality [1]. These complications of diabetes, such as nephropathy, retinopathy, neuropathy, impaired wound healing, and accelerated atherosclerosis, are implicated in a large number of cellular and subcellular changes in vessels [2]. The previous study found that vascular endothelial growth factor (VEGF) was involved $d$ at diabetic complications of pathogenesis [3]. VEGF is a growth factor that induces angiogenesis in vascular endothelial cells [4]. Many studies have found that serum VEGF levels were elevated in patients with diabetes complications [5]. The synthesis and secretion of VEGF are affected by several factors, including gender, hypoxia, hyperglycemia, smoking, blood lipids, inflammatory reaction, and activated stress axes [6]. And therefore, our aim study was to evaluate the relation of VEGF with hypoxia-inducible factor 1-alpha (HIF-1 $\alpha$ ), control glycemic, and lipid profile at T2DM who attended primer health-care center in and around Medan city.

\section{Materials and Methods}

This study used 135 samples with T2DM; we recruited them from the primary health care in Medan city and primary health care in Binjai and Stabat city, North Sumatera, Indonesia. Our study was conducted from Mei to August 2020. Patients with known diabetics taking oral hypoglycemic agents or managed with diet 
or using insulin for the glycemic control were included in the study. Permission from the Institutional Review Committee was obtained. Patients were informed of the study's detail, and written consent was obtained from the patients before they participated in the study. Because of the pandemic coronavirus disease 2019 (COVID-19) in our country, we used personal protective equipment to prevent transmission of the viral COVID-19, and all the samples used the mask when attending the clinic.

We measured height and weight with the subjects standing in light clothes. Body mass index (BMI) was calculated as the weight in kilograms divided by the square of the height in meters $\left(\mathrm{kg} / \mathrm{m}^{2}\right)$. Blood pressure values were taken as the mean of two measurements after the subjects had been seated for at least $5 \mathrm{~min}$. Subjects fasted overnight to provide a blood specimen. Blood samples were collected (using syringe) and transferred to Paramitha Clinical Laboratory immediately to be conducted fasting blood sugar (FBS), glycosylated hemoglobin ( $\mathrm{HbA} 1 \mathrm{c})$, and lipid profile. Blood sugar levels were examined using hexokinase methods, glycosylated hemoglobin using high-performance liquid chromatography methods, lipid profile using direct CHOD PAP, and GPO PAP. We examined the glycosylated hemoglobin test for patients because this examination is the gold standard for T2DM patients. We used ELISA methods for examining VEGF and HIF-1 $\alpha$. The process underwent in the laboratory medical faculty of Sumatera Utara.

\section{Statistical analysis}

We used SPSS version 24.0 (SPSS Inc., Chicago, Illinois) statistical software for statistical analysis. Shapiro-Wilk tested all the variables in this sample of the study, the standard distribution variables $(p>0.005)$ were tested by parametric correlation test, but the abnormal distribution variables $(p<0.005)$ were tested by Pearson correlation.

\section{Results}

We evaluated clinical and laboratory findings in 135 patients with T2DM. Of the total number of subjects, $32.6 \%$ (44) were male, and $67.4 \%$ (91) of the subjects were female. Controlled T2DM found 58 samples (43\%) and 77 samples (57\%) with uncontrolled T2DM. The age median was 57 years old by the interval 35-79 years old. The minimum BMI of the samples were $17.63 \mathrm{~kg} / \mathrm{m}^{2}$ and a maximum of $46.44 \mathrm{~kg} / \mathrm{m}^{2}$ with a mean of BMI $26.01 \mathrm{~kg} / \mathrm{m}^{2}$ and SD $5.3 \mathrm{~kg} / \mathrm{m}^{2}$. The minimum abdominal circumference was $64 \mathrm{~cm}$ and the maximum $121 \mathrm{~cm}$, and the mean $91.35 \mathrm{~cm}$ and SD $10.89 \mathrm{~cm}$. The minimal blood pressure of the samples were $98 / 60 \mathrm{mmHg}$ and the maximal $216 / 113 \mathrm{mmHg}$, and the mean blood pressure 145.43/86.22 $\mathrm{mm} \mathrm{Hg}$. The samples' illness lasted until 30 years, with the median duration of illness 5 years. The minimum FBS of the sample was $73 \mathrm{mg} / \mathrm{dL}$, and the maximum of BSL levels was $610 \mathrm{mg} / \mathrm{dL}$ and the median $222 \mathrm{mg} / \mathrm{dL}$. The minimum $\mathrm{Hba} 1 \mathrm{C}$ value is $4.7 \%$, and the maximum value is $15.2 \%$, with a median of $8.6 \%$. The median of cholesterol levels of the samples $212(111-342) \mathrm{mg} /$ $\mathrm{dL}$, the median high-density lipoprotein (HDL) levels 46 (24-77) $\mathrm{mg} / \mathrm{dL}$, the median low-density lipoprotein (LDL) $124(50-259)$ and the median triglycerides (TG) level 205 (49-1157) mg/dL. The median of HIF-1 $\alpha$ level was $1.04(0.02-13.96) \mathrm{mg} / \mathrm{dL}$ and the median of VEGF levels 428.89 (111.64-75421.89) mg/dL. Furthermore, in our study, we found a significant correlation between VEGF with FBS, HDL, and HIF-1 $\alpha$ in T2DM patients ( $p$ $<0.005)$. There was no significant correlation between VEGF with age, BMI, abdominal circumference, blood pressure, duration of illness, HbA1c, cholesterol, LDL, and TG ( $p>0.005)$. We can see in Tables 1 and 2 .

Table 1: Characteristic samples

\begin{tabular}{llllll}
\hline Characteristics & Median & Mean & SD & $\mathrm{R}$ & $\mathrm{p}$ \\
\hline Age (years) & $57(35-79)$ & - & - & 0.035 & 0.688 \\
Gender & & & & & 0.442 \\
BMI $\left(\mathrm{kg} / \mathrm{m}^{2}\right)$ & $24.44(17.63-46.44)$ & 26.01 & 5.3 & -0.030 & 0.726 \\
Abdominal circumstance $(\mathrm{cm})$ & $90(64-121)$ & 91.35 & 10.89 & -0.10 & 0.911 \\
TDS $(\mathrm{mmHg})$ & $144(98-216)$ & 145.43 & 23.35 & -0.46 & 0.592 \\
TDD (mmHg) & $84(60-113)$ & 86.22 & 10.40 & -0.56 & 0.521 \\
Duration of diabetes (years) & $5(1-30)$ & - & 6.2 & 0.023 & 0.794 \\
\hline BMl: Body mass index. & & & & &
\end{tabular}

In our study using the Spearman correlation test, we found that there was not a significant correlation between VEGF with age, BMI, abdominal circumstance, duration of illness, and blood pressure $(p>0.05)$. We can see in Table 1.

Table 2: Data marker metabolic sample and Pearson correlation test of VEGF with the metabolic marker

\begin{tabular}{llllll}
\hline $\begin{array}{l}\text { Metabolic } \\
\text { markers }\end{array}$ & Median & Mean & SD & $\mathrm{R}$ & $\mathrm{p}$ \\
\hline FBS & $222(73-610)$ & 247.56 & 131.59 & $-0.199^{*}$ & 0.02 \\
HbA1c & $8.6(4.7-15.20)$ & 8.93 & 2.58 & -0.123 & 0.154 \\
Cholesterol & $212(111-342)$ & 212.26 & 45.34 & 0.052 & 0.551 \\
LDL & $124(50-259)$ & 126.18 & 37.33 & 0.107 & 0.217 \\
HDL & $46(24-77)$ & 46.87 & 11.45 & $-0.180^{*}$ & 0.037 \\
TG & $205(49-1157)$ & 231.07 & 139.11 & 0.125 & 0.150 \\
HIF-1a & $1.04(0.02-13.96)$ & 1.99 & 2.65 & $0.707^{* *}$ & 0.000 \\
VEGF & $428.89(111.64-75421.89)$ & 1468.13 & 6839.20 & - & - \\
\hline VEGF: Vascular endothelial growth factor, HIF-1a: Hypoxia-inducible factor 1-alpha, FBS: Fasting blood \\
sugar, HbA1c: Hemoglobin A1c, TG: Triglyceride, HDL: High-density lipoprotein, LDL: Low-density \\
lipoprotein. VEGF was correlated with the previous metabolic markers and shod be labeled with - -
\end{tabular}

\section{Discussion}

In our study the samples were more females $(67.4 \%)$ than males $(32.6 \%)$ with T2DM. The high proportion of females in this study may be due to the nature of the population admitting to primary health care in that more of them seek medical attention than men in favor of having more free time because most of them were housewives. Our study aimed to evaluate the correlation between VEGF levels with HIF-1 $\alpha$, 
glycemic control, and other metabolic markers in T2DM patients. In our study, we found that there was a significant correlation between VEGF with FBS, HDL, and $\mathrm{HIF}-1 \alpha, \mathrm{p}<0.05$. Moreover, there was no significant correlation between VEGF with age, gender, BMI, abdominal circumference, blood pressure, $\mathrm{HbA1c}$, and other metabolic markers (cholesterol, LDL, and TG), p $>0.05$. The detailed other research found no significant relationships between VEGF and sex, age, BMI, HbA1c, FBG, TG, TC, HDL-C, LDL-C, UA, or HCY [7]. Nevertheless, our study found a significant correlation between VEGF with FBS, HDL, and HIF-1 $1 \alpha$. The other study found that VEGF levels in plasma were positively correlated with glycemic control indicators (FBG and $\mathrm{HbA} 1 \mathrm{c}$ ) and demonstrated a close association between hyperglycemia and VEGF in T2DM patients [8]. This study found a significant negative correlation between VEGF with FBS, and there was a positive and enormously significant correlation between VEGF with HIF-1 $\alpha$. International Diabetes Federation estimated that the number of diabetes cases globally was approximately 366 million, constitutes approximately $90-95 \%$ and up to $80 \%$ of mortality associated with micro- or macro-vascular complication [9], [10]. Many factors cause complications, but the most crucial factor was that chronic hyperglycemia causes the pathological change of hypoxia [11]. The other researchers demonstrated that the expression of HIF-1 $\alpha$ and VEGF was positively correlated with diabetic retinopathy severity. HIF- $1 \alpha$ and VEGF play an essential role in the process of retinopathy induction and vascularization [12]. Hyperglycemia and hypoxia are suggested to play essential pathophysiological roles in the complications of diabetes, which may result from an inadequate response of the tissues to low oxygen tension [13]. VEGF includes a family of growth factors that act on endothelial cells regulated by hypoxia and promote angiogenesis, increases permeability in the vasculature, and is also known as a significant regulator of endothelial proliferation, migration, and survival [14].

VEGF and HIF-1 $\alpha$ are the body's defense mechanisms against compensating cells in a hypoxic state, induced by a chronic hyperglycemic state that causes hypoxic tissue, with the secretion of VEGF protein causing vasodilation and an angiogenesis process [15]. Increased VEGF concentration indicates the progression of various complications in DM and is related to the severity of a complication and a compensatory reaction to damage to endothelial cells [16]. However likely, retinal VEGF levels are initially elevated due to a reaction against retinal hypoxia or ischemia in diabetes to maintain endothelial function and circulation due to pericytes loss and acellular capillaries. This increase in VEGF is probably a tissue response to increase survival [17].

There was a negative correlation negative between VEGF with FBS in this study, which means increased VEGF levels and decreased FBS levels. It was likely with other research that showed acute hypoglycemia is associated with an increase in serum VEGF in humans and increasing VEGF secretion during hypoglycemic conditions correlated positively with the maintenance of cognitive performance during hypoglycemia where they found that acute hyperglycemia is significantly associated with an elevation in serum VEGF in human [18]. Moreover, the research suggested that VEGF release during hypoglycemia is positively correlated to neurocognitive function keeping, too [18]. This study found a negative correlation between VEGF with HDL, the same as the previous studies [19].

Many studies have found that VEGF is involved in the pathogenesis of diabetic complications [20], [21]. As we know that hyperglycemia-induced diacylglycerol, a lipid molecule, activates protein kinase $C$ in the vascular tissues, and then turn promotes VEGF signaling, resulting in diabetic microvascular complications [22]. But still, the other factors, including hypoxia, gender, smoking, elevated levels of blood lipids, inflammatory status, and activated stress axes, may affect the synthesis and secretion of VEGF; among them, the significant physiological stimulus for VEGF expression is the cellular hypoxia [23], [24].

\section{Conclusion}

We conclude that in the study of diabetic patients, the relationship between VEGF levels was positive and firmly with the $\mathrm{HIF}-1 \alpha$ and negatively correlated with FBS and HDL.

VEGF and HIF-1 $\alpha$ were a positive and strong correlation, but the correlation between VEGF and FBS can be negative.

\section{References}

1. Morrish NJ, Wang SL, Stevens LK, Fuller JH, Keen H. Mortality and causes of death in the WHO multinational study of vascular disease in diabetes. Diabetologia. 2001;44(2):S14-21. https:// doi.org/10.1007/pl00002934

PMid:11587045

2. Costa PZ, Soares R. Neovascularization in diabetes and its complications. Unraveling the angiogenic paradox. Life Sci. 2013;92(22):1037-45. https://doi.org/10.1016/j.Ifs.2013.04.001 PMid:23603139

3. Kroll P, Rodrigues EB, Hoerle S. Pathogenesis and classification of proliferative diabetic vitreoretinopathy. Ophthalmologica. 2007;221(2):78-94. https://doi.org/10.1159/000098253 PMid:17380062

4. Leung DW, Cachianes G, Kuang WJ, Goeddel DV, Ferrara N Vascular endothelial growth factor is a secreted angiogenic mitogen. Science. 1989;246(4935):1306-9. https://doi. 
org/10.1126/science.2479986

PMid:2479986

5. Witmer AN, Vrensen GF, Van Noorden CJ, Schlingemann RO Vascular endothelial growth factors and angiogenesis in eye disease. Progr Retinal Eye Res. 2003;22(1):1-29 https://doi. org/10.1016/s1350-9462(02)00043-5

PMid:12597922

6. Guo L, Jiang F, Tang YT, Si MY, Jiao XY. The association of serum vascular endothelial growth factor and ferritin in diabetic microvascular disease. Diabetes Technol Ther. 2014;16(4):224-34. PMid:24279470

7. Sun X, Zhang H, Liu J, Wang G. Serum vascular endothelial growth factor level is elevated in patients with impaired glucose tolerance and Type 2 diabetes mellitus. J Int Med Res. 2019;47(11):5584-92. https://doi.org/10.1177/0300060519872033

PMid:31547733

8. Zhang Q, Fang W, Ma L, Wang ZD, Yang YM, Lu YQ. VEGF levels in plasma in relation to metabolic control, inflammation, and microvascular complications in type- 2 diabetes: A cohort study. Medicine. 2018;97(15):e0415.

PMid:29642210

9. Whiting DR, Guariguata L, Weil C, Shaw J. IDF diabetes atlas: Global estimates of the prevalence of diabetes for 2011 and 2030. Diabetes Res Clin Pract. 2011;94(3):311-21. https://doi. org/10.1016/j.diabres.2011.10.029 PMid:22079683

10. Silvestre JS, Levy BI. Molecular basis of angiopathy in diabetes mellitus. Circ Res 2006;98(1):4-6. PMid:16397150

11. Lei RJ, Hu D, Zhang P, Sun LJ, Bai Q, Min J. Effect of anoxia on expression of angiopoietin-1 and angiopoietin-2 in retinal pigment epithelial. Recent Adv Ophthalmol 2013;33(5):435-6.

12. Yan HT, Su GF. Expression and significance of HIF-1 $\alpha$ and VEGF in rats with diabetic retinopathy. Asian Pac J Trop Med. 2014;7(3):237-40. https://doi.org/10.1016/ s1995-7645(14)60028-6

PMid:24507647

13. Cameron NE, Eaton SE, Cotter MA, Tesfaye S. Vascular factors and metabolic interactions in the pathogenesis of diabetic neuropathy. Diabetologia. 2001;44(11):1973-88. https://doi. org/10.1007/s001250100001 PMid:11719828

14. Ferrara N. Vascular endothelial growth factor: Basic science and clinical progress. Endocr Rev. 2004;25(4):581-611. https:// doi.org/10.1210/er.2003-0027 PMid: 15294883

15. Chintala H, Krupska I, Yan L, Lau L, Grant M, Chaqour B. The matricellular protein $\mathrm{CCN} 1$ controls retinal angiogenesis by targeting VEGF, Src homology 2 domain phosphatase-1 and Notch signaling. Development. 2015;142(13):2364-74. https:// doi.org/10.1242/dev.121913 PMID:26002917

16. Braun L, Kardon T, Reisz-Porszasz ZS, Banhegyi G, Mandl J. The regulation of the induction of vascular endothelial growth factor at the onset of diabetes in spontaneously diabetic rats. Life Sci. 2001;69(21):2533-42. https://doi.org/10.1016/ s0024-3205(01)01327-3 PMid:11693260

17. Ferrara N. Vascular endothelial growth factor: Basic science and clinical progress. Endocr Rev. 2004;25(4):581-611. https:// doi.org/10.1210/er.2003-0027 PMid:15294883

18. Mohamed AH, Zaidan HK. Evaluation of vascular endothelia growth factor level of diabetic peripheral neuropathy patients in Babylon Province. J Pharm Sci Res. 2019;11(1):247-50.

19. Dantz D, Bewersdorf J, Fruehwald-Schultes B, Kern W, Jelkmann W, Born J, et al. Vascular endothelial growth factor: A novel endocrine defensive response to hypoglycemia. J Clin Endocrinol Metab. 2002;87(2):835-40. https://doi.org/10.1210/ jcem.87.2.8215

PMid:11836329

20. Abu-Yaghi NE, Abu Tarboush NM, Abojaradeh AM, Al-Akily AS, Abdo EM, Emoush LO. Relationship between serum vascular endothelial growth factor levels and stages of diabetic retinopathy and other biomarkers. J Ophthalmol. 2020;2020:8480193. https://doi.org/10.1155/2020/8480193 PMid:32774911

21. Aiello LP, Wong JS. Role of vascular endothelial growth factor in diabeticvascularcomplications. Kidney IntSuppl.2000;77:S113-9. https://doi.org/10.1046/j.1523-1755.2000.07718.x PMid:10997700

22. Watanabe T. Is vascular endothelial cell growth factor (VEGF) involved in the pathogenesis of diabetic nephropathy? Nephrology (Carlton). 2007;12(3):S27. https://doi. org/10.1111/j.1440-1797.2007.00879_2.x

23. Pathak D, Gupta A, Kamble B, Kuppusamy G, Suresh B. Oral targeting of protein kinase $C$ receptor: Promising route for diabetic retinopathy? Curr Drug Deliv. 2012;9(4):405-13. https:// doi.org/10.2174/156720112801323080 PMid:22520069

24. Sandhofer A, Tatarczyk T, Kirchmair R, Iglseder B, Paulweber B, Patsch JR, et al. Are plasma VEGF and its soluble receptor sFlt-1 atherogenic risk factors? Cross sectional data from the SAPHIR study. Atherosclerosis. 2009;206(1):265-9. https://doi. org/10.1016/j.atherosclerosis.2009.01.031

PMid:19237157 